\title{
Abortion and the COVID-19 pandemic: insights for Latin America
}

\author{
Aborto e a pandemia da COVID-19: lições para \\ América Latina
}

\section{Aborto y pandemia de COVID-19: reflexiones para Latinoamérica}

\author{
Flávia Bulegon Pilecco 1,2 \\ Cecilia Anne McCallum 3 \\ Maria da Conceição Chagas de Almeida 2,4 \\ Flávia Jôse Oliveira Alves 2,3 \\ Aline dos Santos Rocha 2,4,5 \\ Naiá Ortelan 2,4 \\ Ligia Gabrielli 2,3 \\ Greice Maria de Souza Menezes 3
}

doi: 10.1590/0102-311X00322320

\begin{abstract}
The COVID-19 pandemic may accentuate existing problems, hindering access to legal abortion, with a consequent increase in unsafe abortions. This scenario may be even worse in low-and middle-income countries, especially in Latin America, where abortion laws are already restrictive and access to services is already hampered. Our objective was to understand how different countries, with an emphasis on Latin Americans, have dealt with legal abortion services in the context of the COVID-19. Thus, we conducted a narrative review on abortion and COVID-19. The 75 articles included, plus other relevant references, indicate that the pandemic affects sexual and reproductive health services by amplifying existing problems and restricting access to reproductive rights, such as legal abortion. This impact may be even stronger in low-and middle-income countries, especially in Latin America, where access to legal abortion is normally restricted. The revision of sources in this article underlines the urgent need to maintain legal abortion services, both from women's perspective, in support of their reproductive rights, but also from that of the international commitment to achieving the Millennium Development Goals. Thereby, Latin American countries must place reproductive rights as a priority on their agendas and adapt legislation to accommodate alternative models of abortion care. Furthermore, our results underscore the need for clear information on the functioning of sexual and reproductive health services as essential for understanding the impact of the pandemic on legal abortion and to identify the groups most affected by the changes.
\end{abstract}

Abortion; COVID-19; Legal Abortion; Reproductive Rights

\author{
Correspondence \\ F. B. Pilecco \\ Universidade Federal de Minas Gerais. \\ Av. Prof. Alfredo Balena 190, sala 803, Belo Horizonte, MG \\ 30130-100, Brasil. \\ flaviapilecco@yahoo.com.br \\ 1 Universidade Federal de Minas Gerais, Belo Horizonte, Brasil. \\ 2 Rede CoVida - Ciência, Informação e Solidariedade, Salvador, \\ Brasil. \\ 3 Instituto de Saúde Coletiva, Universidade Federal da Bahia, \\ Salvador, Brasil. \\ 4 Instituto Gonçalo Moniz, Fundação Oswaldo Cruz, Salvador, \\ Brasil. \\ 5 Escola de Nutrição, Universidade Federal da Bahia, Salvador, \\ Brasil.
}




\section{Introduction}

Despite the ample heterogeneity, Latin American countries share a common ambiguity surrounding interventions in the reproductive process. The hegemonic value systems in these countries are anchored in religious patriarchalism, with a markedly conservative position on abortion 1,2, contributing to the amplification of socioeconomic gender inequalities 3 . Although sexual and reproductive health services frequently malfunction, offering an irregular and limited supply of contraceptive methods 4,5 , the region's recent reduction in fertility owes much to the expanded use of contraception. Abortion, although illegal in most countries, is widely practiced 6 . In this context, the COVID-19 epidemic may be accentuating existing problems, weakening the regular provision of contraception, and hindering the already restricted access to legal abortion, with a consequent increase in unsafe abortions. This article explores these questions.

Historically, epidemics and economic crises disproportionately affect women, especially those already facing barriers to accessing healthcare 7 . A reduction in reproductive planning services occurred during other epidemics, such as Ebola, in West Africa, resulting in an increase in unintended pregnancies and elevated maternal mortality ${ }^{8}$. In the context of such previous outcomes, on February $6^{\text {th }}$, 2020, the United Nations Population Fund (UNFPA), at its regional office for Asia and the Pacific, published a document warning that the lack of adequate sexual and reproductive health services causes significant public health problems during epidemics 9 . On March 25th, 2020, the World Health Organization (WHO) directed countries to identify essential services that should be kept active, including services related to sexual and reproductive health and legal abortion ${ }^{10}$. Along with UNFPA and WHO, many other international organizations reaffirmed that contraception and safe abortion care are essential during pandemics 11. In line with these multilateral organization's concern, there is evidence of an increase in the search for information and in demand for abortion services after the beginning of the COVID-19 pandemic 12,13. However, much of this demand will not be met due to restrictions on access to these services $14,15,16$.

Low- and middle-income countries deserve special attention, since, besides the high unmet need for contraception, they have higher rates of unintended pregnancies and abortions compared to high-income countries, despite their restrictive abortion laws ${ }^{17}$. Even before the pandemic, sexual and reproductive health services in low- and middle-income countries were already experiencing functional problems, with women having difficulty in accessing contraception and, in particular, safe abortion 18,19. In the current scenario, Riley et al. 20 estimate that a $10 \%$ decline in the use of short- and long-term reversible contraceptives in these countries would result in an additional 49 million women with unmet demand for contraception and 15 million unintended pregnancies 20 . These authors also estimated that, if $10 \%$ of women that were entitled to legal and safe abortion in these countries stopped accessing these services and resorted to unsafe abortion, there would be an additional 3.3 million unsafe abortions 20. Only in Latin America, the UNFPA predicts that 18 million women will lose regular access to modern contraceptives during the pandemic 21 .

Latin America has extremely restrictive laws on abortion. Even before the pandemic, with the exception of Cuba, Guyana, Uruguay and Mexico City, where abortion is permitted on request, and Belize, Barbados, and Saint Vincent and the Grenadines, where abortion is permitted on broader social or economic grounds, the access 17 was already limited. When permitted by law, obtaining the procedure can be difficult due to the small number of services available, the constant threats of service interruption, and even conscientious objection or distrust by health professionals 18,22.

Despite all these restrictions, abortion remains a common practice in Latin America. In 20152019 , the rate of unintended pregnancies in the region (69 per 1,000 women of reproductive age) was almost twice that of Europe and North America (35 per 1,000 women of reproductive age), and around half of them ended in induced abortion. A significant proportion of these are self-managed medical abortions using misoprostol, a medication that has replaced invasive methods, thus decreasing morbidity and mortality due to abortion 23 . Knowledge about self-managed medical abortion was built and disseminated by Brazilian women in late 1980s and early 1990s 24. In Latin America, this knowledge is currently passed on by feminist networks, which also provide support and even the medication 25. These networks were responsible for meeting part of the demand for abortion during the Zika epidemic 26 . Another part of the demand for medication is supplied by drug or gender drug 
trafficking networks 27. Acquisition from such illicit sources is not always accompanied by correct information on the use of misoprostol. Therefore, the substitution of invasive methods is not equal for all women, thus reproducing existing inequalities of class and race in access to the medicine and to the information necessary for its proper use 28.

Given the above, our goal in preparing this article was to understand how different countries, with an emphasis on Latin America, have dealt with legal abortion services in the context of the COVID-19 pandemic.

\section{Methods}

We carried out a narrative review of the literature produced on the subject up until March 10th 2021, in the following databases: LitCovid (a curated literature hub exclusive for COVID-19 developed with the support of the U.S. National Institutes of Health's intramural research program), Global Index Medicus (GIM), Virtual Health Library (BVS, in Portuguese) and Journal Storage (JSTOR). Original and review articles, comments, letters to the editor, and opinion articles were included. Searches were performed using the following search terms: LitCovid (English keywords only; we did not include descriptors related to COVID-19, since it is an exclusive curator on the topic) - https:// www.ncbi.nlm.nih.gov/research/coronavirus/, (abortion OR "termination of pregnancy" OR "pregnancy termination” OR “induced abortion”); GIM (Keywords in English, Portuguese and Spanish) https://www.globalindexmedicus.net/, tw:((abortion OR "termination of pregnancy" OR "pregnancy termination" OR "induced abortion” OR aborto OR "aborto induzido" OR “aborto provocado" OR "interrupción del embarzo" OR "término del embarazo" OR "aborto inducido") AND (COVID-19 OR SARS-COV-2 OR coronavirus OR "novel coronavirus” OR ncov OR cov OR "2019-nCov" OR "novo coronavírus" OR "nuevo coronavirus”)) AND (year_cluster:[2020 TO 2020]); BVS (Keywords in English, Portuguese and Spanish; searches made in title, abstract and subject; restricted to research articles) - http://bvsms.saude.gov.br/, tw:((abortion OR "termination of pregnancy" OR "pregnancy termination” OR "induced abortion” OR aborto OR "aborto induzido” OR "aborto provocado” OR "interrupción del embarzo" OR "término del embarazo” OR "aborto inducido”) AND (covid-19 OR sars-cov-2 OR coronavirus OR "novel coronavirus” OR ncov OR cov OR "2019-nCov" OR "novo coronavírus” OR “nuevo coronavirus”)) AND (year_cluster:[2020 TO 2020]) AND (type: (“article”)); JSTOR (English keywords; restricted to articles, reviews and research reports) - https://www.jstor. org/, ((abortion OR "termination of pregnancy" OR "pregnancy termination" OR "induced abortion") AND (COVID-19 OR SARS-CoV-2 OR coronavirus OR "novel coronavirus” OR nCOV OR cov OR “2019-nCov”)).

The review focused on countries in Latin America; however, it adopted a broader and comparative approach, to contemplate what has been done in other countries regarding the abortion services during COVID-19 times. We limited the search to studies published from 2020 until March 10th 2021. Original and review articles, comments, letters to the editor, and opinion articles were included.

All articles relevant to the topic were read in full and included in this review. Due to the scarcity of studies on abortion services in Latin America, another survey of articles was conducted on Google Scholar (https://scholar.google.com), which included the names of Latin American countries, abortion (in each country's official language) and COVID-19. Finally, documents from the gray literature and from the websites of multilateral organizations working on the theme of abortion, such as WHO, UNFPA, Ministries of Health of Latin American countries, the Guttmacher Institute, and other nongovernmental organizations (NGOs) aimed at to sexual and reproductive health, were included. 


\section{Results and discussion}

The final search resulted in 668 studies (LitCovid - 128; GIM - 15; BVS - 422; JSTOR - 103), of which 111 were excluded because of duplicates. Of the remaining 557, seven articles were excluded due to linguistic reasons (four were written in Chinese, one in Dutch, one in German and one in Russian), eleven because they were studies conducted in animals (wrong population), and nine because they were a wrong publication type (appendices, annexes, notes, references). Of the 530 remaining, 248 were on the effects of COVID-19 on health, on health services and the treatments used to fight the disease, and 20 were on testing for COVID-19. In total, 54 papers focused on COVID-19 and pregnancy or the risk of transmission of the disease through abortion, 11 on the effects of the disease on the fetus/child, and eight on other issues on sexual and reproductive health. Twenty-one studies were excluded because they focus on spontaneous abortion and seven because they focused on the history of abortion/abortion before the pandemic/men's role in abortion/post-abortion infections. Other 82 articles were excluded because they thematized issues unrelated to abortion in the days of COVID-19. Finally, 77 articles were read in full, from which 75 were included in this review (exclusions were due to the articles being clinical reports of abortion during the pandemic, not addressing health services) (Figure 1).

Although it is a narrative review of the literature, this article has the merit of the breadth of the search process, which included, besides the strategy presented here, complementary searches on Google Scholar, gray literature and on multilateral organizations websites.

In what follows, we present an overview of what has been produced about the effect of the pandemic on abortion services, in general, and, more specifically, in Latin America.

\section{The COVID-19 pandemic and legal abortion services worldwide}

The COVID-19 pandemic has exposed the vulnerability of abortion services worldwide. Although threats to reverse legalization and thereby to restrict access to safe abortion are neither new nor limited to the context of the pandemic, they are of greater concern under the current circumstances, in which women are even more exposed to unintended pregnancy.

Supporters of the closure of legal abortion services base their argument on the scarcity of human and financial resources caused by the pandemic. They argue that abortion is an elective procedure and that equipment and resources may be better allocated. However, these points are fallacious. Regarding the allocation of resources, surgical abortion requires minimal equipment and, in most cases, it does not require hospitalization, since it may be performed in extra-hospital settings, such as in health clinics. Moreover, medical abortion may take place at home (not requiring, in general, the use of personal protective equipment (PPE) 14,29,30. The maintenance of pregnancy, in turn, implies a broad use of these resources during prenatal, delivery, and puerperium care 14,29.

The understanding that, when not practiced therapeutically, abortion is an elective procedure, contradicts guidelines and the positions expoused by experts, and public health organizations 32,33 . The term "elective", in general, is used for health procedures that can be scheduled, planned and, if necessary, postponed, but never canceled. In the context of the COVID-19 pandemic, it makes sense for elective procedures to be postponed and performed when there is greater security. In many Latin American countries, elective procedures are performed in hospitals, in a scheduled and planned way; however, this is not the case of abortion, which, together with prenatal, childbirth and puerperium care, is time-dependent. As reproductive rights, these procedures must be guaranteed. In the specific case of abortion, postponement implies the following: (i) increased procedural complexity; (ii) greater risks associated with women's physical and mental health; (iii) higher costs for the health system; and (iv) making it unfeasible, due to legal and ethical impediments, depending on the state or country 14,32,34.

Lawmakers in countries and states with more conservative views on abortion have used pandemic containment measures to restrict access to these services. Some countries did this through legal loopholes such as in several US states $14,16,30,35,36,37,38$. Others, such as Italy 39,40 and India 41 , restricted access by reducing the supply of services and diverting professionals to assist patients with COVID-19. Malta, for example, with one of the most restrictive abortion laws in Europe, made it even more difficult by banning flights, thus preventing women from seeking abortion in other countries or 
Figure 1

Selection of articles included in the narrative review.

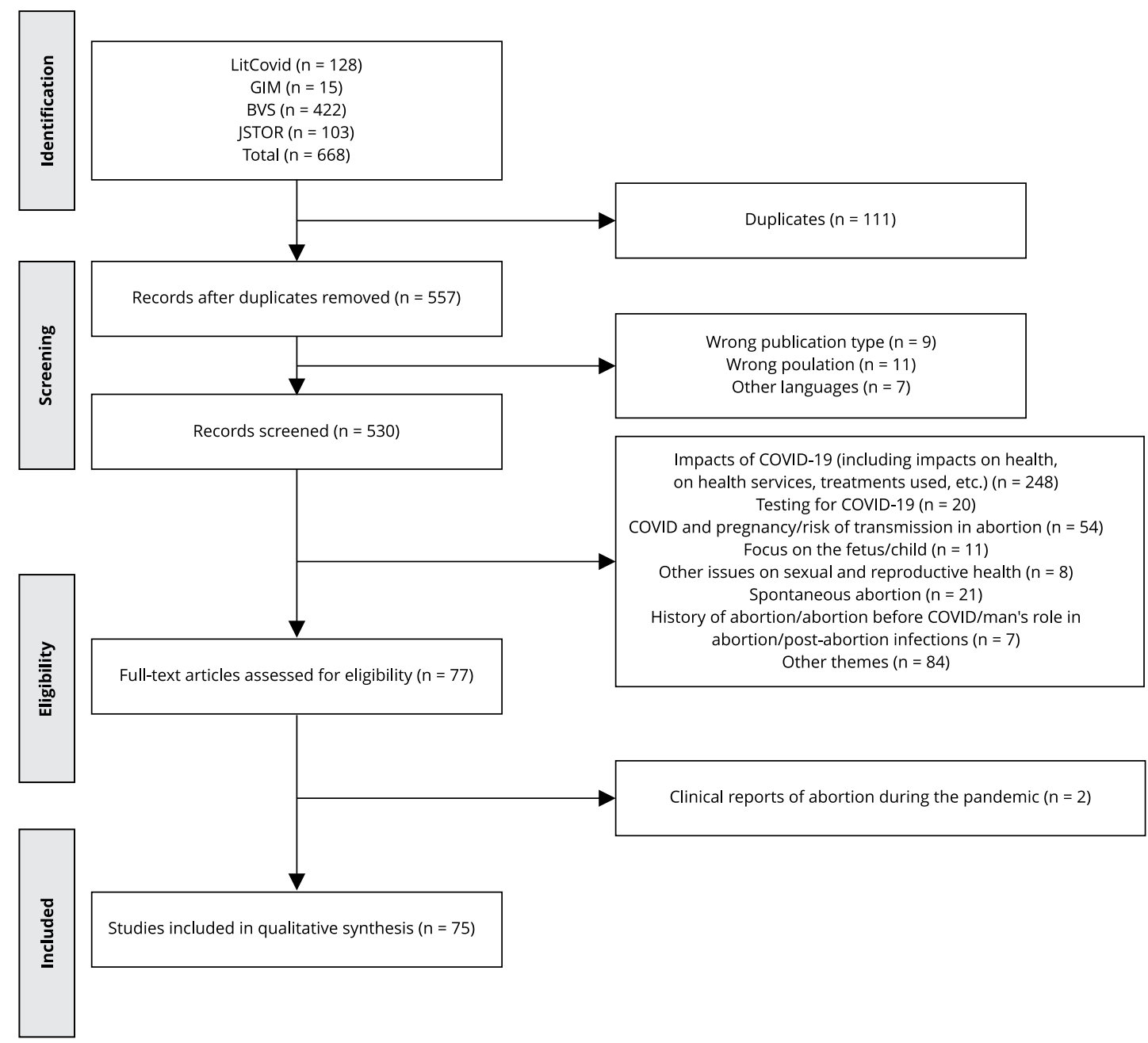

BVS: Virtual Health Library; GIM: Global Index Medicus; JSTOR: Journal Storage; LitCovid: a curated literature hub exclusive for COVID-19 developed with the support of the U.S. National Institutes of Health's intramural research program.

receiving abortion pills in the country ${ }^{42}$. And other countries, like Poland 42 , tried unsuccessfully to pass laws banning abortion in the country.

The consequences of interrupting the provision of abortion services will be disastrous in both the short and long terms. It will be even worse to the most vulnerable women - black, indigenous, Latin, immigrants, especially those without documents, minors, people with some type of disability, women in rural contexts, and victims of intimate partner violence 43,44 - who will suffer the consequences of this curtailing of services. Finding access to the procedure impeded, they will experience an increase in cost and risk, or even need to resort to unsafe abortion 30,35,45,46. These barriers to access can also compel many women to continue with a pregnancy that, for various reasons, they had decided to terminate. Studies found that women that carry on with unintended pregnancies report worse levels of physical and mental health, greater economic restrictions, and more violence committed by the intimate partner than women who access abortion 47,48,49. 
Despite the setbacks, some proposals to enable the continuity of abortion care have been made and adopted. For pregnancies up to 12 weeks, self-managed medical abortion is indicated, with the use of mifepristone and misoprostol, without prior testing, with guidance and advice provided via telehealth (through telephone or internet) 31,5,51,52,53,54,55. A recent systematic review published in Cochrane indicated that self-administration of drugs, if well targeted, is as effective for the completion of abortion as the surgical procedure performed by a professional 56 .

Moreover, some authors argue that the use of self-managed medical abortion challenges hierarchies of power and truth constituted in medicine, since it centers abortion on women and, therefore, consists of an innovative form of care 53,54 . There is also the proposal of protocols that do not require ultrasound and pre-abortion blood tests. These protocols are based on evidence that clinical outcomes are not improved by performing these tests 57 . The use of these new protocols for self-managed medical abortion is indicated in the absence of risk of ectopic pregnancy, if the woman is reasonably sure of the date of her last menstruation, is not using hormonal contraception, has regular menstrual cycles, and has no other contraindications. Otherwise, the use of ultrasound is still recommended 34. However, there is no proposed protocol for pregnancies that are over 12 weeks. When surgical abortion is the only option (either due to advanced gestational age, a lack of privacy at home, or the threat of domestic violence), unnecessary contact in health services should be avoided, with the provision of pre- and post-procedural counseling via telehealth, pre-procedure symptom tracking, restriction of the number of people present in the procedure room, adequate use of PPE, and decontamination of the post-procedure site. In such cases, the use of general anesthesia is best avoided, thus reducing the need for mechanical ventilation (eliminating the generation of aerosols), requiring fewer professionals, and allowing greater distance in the procedure room 11,34,43.

Some countries, such as the United Kingdom 58,59,60, acting on the basis of the understanding that it is important to maintain access to abortion services and ensure that the procedure is performed at the right time, encouraged the use of remote consultations during the pandemic. Others, such as Finland and Scotland, extended the period in which medical abortion is permitted 61 . France not only maintained access but encouraged remote consultations and extended the period for abortion 61,62 . In addition to establishing new modalities of access to abortion as part of the response to the pandemic, the process of providing legal abortion services has been accelerated in other countries, for example in Northern Ireland (excluded from the United Kingdom Abortion Act until 2019). Thus, women do not need to travel to England in search of this service, as they did previously, reducing the risk of contagion by COVID-19. Besides, in March 2020, the New Zealand parliament decriminalized abortion after decades of campaigns 63 .

\section{Legal abortion and COVID-19: Latin American specificities}

Few articles on Latin America address the changes and continuities in abortion services due to the COVID-19 pandemic. Most of the information available comes either from feminist activists and NGO working with sexual and reproductive health or from the governments of the countries themselves. In the region, the pandemic poses an additional obstacle to the already difficult task of obtaining legal and safe abortion 64. The Brazilian NGO Gênero e Número pointed out that, while governments in Argentina, Mexico, and Colombia aligned themselves with the WHO, which declared that sexual and reproductive health services are essential during the pandemic, Chile and Brazil did not position themselves 5 .

In Argentina, in addition to legal abortion being treated as an essential service in times of a pandemic, a free telephone service was available to answer questions from users and receive complaints about provinces that have not maintained it. In the Mexican capital, where abortion is legalized in any situation until the 12th gestational week, access to teleconsultations was expanded and the use of medical abortion was privileged, to reduce invasive and face-to-face procedures. In Colombia, the government guaranteed the continuity of voluntary abortion services 5, and the NGO "Oriéntame" created a consultation service via telephone and WhatsApp to guide women on performing a self-managed medical abortion, within the situations permitted by law. In these cases, medication is sent by mail 65 .

However, the media and feminist organizations have reported that women are experiencing difficulties in accessing sexual and reproductive health services, especially for legal abortion. Contracep- 
tion acquisition has been hampered by distance measures in Honduras and shortages in Guatemala and especially in Chile, in which the access to misoprostol has also been hindered 66. In Mexico City, conservative organizations have been collecting signatures requesting the closure of abortion clinics during the pandemic. In Argentina, access to legal abortion also appears to be suffering from the effects of the health crisis 67 . Nevertheless, this situation may change with the recent decriminalization and legalization of abortion, approved by the Chamber of Deputies and the Senate 68. In Colombia, activists fear that restrictions on displacement will further hamper access to legal abortion, which, even before the pandemic, was already limited 5 . This difficulty in carrying out a legal abortion provided by the state is reflected in the increased demand for feminist organizations. Moreover, these restrictions tend to be even greater among Venezuelan migrants living in Colombian territory. In Bolivia, legal terminations of pregnancy and post-abortion medical care decreased due to quarantine 5 . However, according to the NGO Ipas - Health. Access. Rights., in this country, searches for information on medical abortion, though not allowed by law, have increased 13. In Ecuador, feminists reported that, even under normal conditions, access to legal abortion had been hampered and that this situation worsened after the onset of the pandemic 5.

In Brazil, the Ministry of Health was slow to take an official position on sexual and reproductive health. In Technical Notes, care for women during the COVID-19 pandemic was to be reduced to the pregnancy-puerperal cycle, excluding contraception and abortion. On May 1st 2020, the Ministry of Health issued another Technical Note recognizing sexual and reproductive health services, including legal abortion, as essential. This document reinforced guidelines in the Policy of Comprehensive Care for Women's Health and reiterated the importance of continuing the services already provided 69. However, three days later, after an intervention by higher echelons of the federal government, the Brazilian Ministry of Health removed the Note. This episode culminated in the dismissal of the Ministry's coordinators of Women's and Men's Health. Thus the Brazilian government, which staunchly opposes women's reproductive rights, reaffirmed its conservative position. In response, several civil society organizations have lobbied against the dismissals and the withdrawal of the Note, and reinforced the importance of maintaining sexual and reproductive health services.

The Pérola Byington Hospital, a reference institution for legal abortion in Brazil's most populous megalopolis, São Paulo, suspended the procedures from March 26th to 30th, 2020, to redirect efforts to confront COVID-19. Assistance was resumed after intervention by the State Public Prosecutor's Office and the Public Defender's Office of the State of São Paulo. However, a survey conducted by the NGO ARTIGO 19, the Az Mina magazine, and the Gênero e Número webpage pointed out that this was not an isolated situation. Abortion services in the country were admittedly scarce even before the pandemic, concentrated in large centers, and had functional problems 18; of the 76 hospitals that actually reported providing abortions in 2019, only 55\% were in operation during the pandemic 70 . Recently, the country experienced an emblematic situation, when a ten-year-old child, who had been repeatedly raped since the age of six, had to go to court to obtain access to the abortion that was her legal right. Her case fits into two situations in which abortion is allowed by law since 1940: in the case of rape, and of risk of life to the pregnant woman. In addition to this unnecessary recourse to an injunction, the child had to travel more than 2,000 kilometers to obtain the procedure, since the nearest legal abortion service refused to perform the procedure, alleging technical restrictions. In a further breach of her rights, her private data was exposed on social networks and, as a result, her access to the health service where she would obtain the procedure was hampered by religious extremists, who picketed the hospital 71 .

This case exposes the difficulties faced by Brazilian and Latin American girls and women seeking access to reproductive health. Notwithstanding legal guarantees, abortion is far from accessible to women, who are often forced to carry on with an unintended pregnancy, even when it is a result of violence. The State, by failing to ensure access to a constitutional right, engenders institutional violence against girls and women. Moreover, although constitutionally Latin American countries proclaim themselves secular, religious influence on state actions is clearly present. In response to the huge public outcry over the case of the pregnant ten-year-old rape victim and on the eve of the Supreme Federal Court's judgement of the Allegation of Breach of Fundamental Precept (ADPF) 442, which could allow abortion at the request of the woman until the 12th gestation period, the Brazilian Ministry of Health issued Ordinances n. 2,282/202072 and n. 2,561/202073, which outlined a set of mea- 
sures to hinder women's access to sexual and reproductive health services, aiming to discourage them from having abortions. Ordinance n. 2,282/2020 intended to force health professionals to notify the police authority of cases of rape, contrary to the Brazilian Ministry of Health's own previous technical standard, as well as to inform women of any risks related to abortion and to offer them the possibility of visualizing the fetus or embryo through ultrasound. Ordinance n. 2,561/2020, however, revoked the obligation to offer fetus visualization, but maintained the other instructions.

The strategies adopted to facilitate access to abortion in cases provided for by law in high income countries and countries in Latin America encounter other legal and operational barriers. In Brazil, for example, attention to abortion in the public system occurs in maternity hospitals, where it is difficult to alter entrenched models of abortion care. Another difficulty is the ban on the marketing of mifepristone 74 and the restriction of misoprostol to hospital use 75 , which prevents self-induced medical abortion at home. There is evidence of the lack of this medication, the use of which is not restricted to abortion, in the public network of the country even before the pandemic ${ }^{76}$. Finally, unequal access to digital technologies limits the offer of distance care, making those belonging to more vulnerable groups and especially poorer women need to expose themselves to the risk of contracting COVID-19 in the search for face-to-face assistance. In this context, partnerships with local health promoters, peer educators, hotlines, and, in the case of Brazil, with community health agents, could be useful to support medical abortion in the community 7.

\section{Conclusions}

In the pandemic scenario of COVID-19, women are seeing their reproductive rights threatened by the action of States, with a reduction in services and supplies related to reproductive health, especially legal abortion. Despite being signatories to the final declarations of World Conferences on Women and despite having adopted the Human Rights framework in the formulation of their women's health policies, several Latin American countries do not use the guidance these documents provide to shape the daily practices of their health institutions.

In Latin America, the adaptations to face restrictions imposed by COVID-19 adopted in other countries have encountered additional obstacles, since Latin American countries, in general, have a more conservative and restrictive position regarding to abortion. In times of a pandemic, these restrictions are even more pronounced. In the region, the scenario has been marked by most government's lack of positioning about the importance of maintaining these services. The restrictions imposed on abortion therefore imply an increase in social and racial inequality as a result of the way governments face the pandemic 30 . Black women in a situation of social vulnerability, notably the young and low-income, who are already excluded from so many other constitutional rights, will seek unsafe alternatives alone and unsupported and often pay with their own lives.

At the time of the writing, the data available on legal abortion services in Latin America was insufficient to provide a picture of the effect of the pandemic on reproductive outcomes. Investigations should monitor this effect in the long term, especially given the possibility of the occurrence of several waves of COVID-19. Besides, these investigations should not only indicate the magnitude of the reduction in access to legal abortion but also uncover which groups are most affected.

Adapting to the new demands on sexual and reproductive health resulting from the pandemic is urgent. Countries must revise their legislation to reduce legal and access barriers, such as the requirement for a prescription for the purchase of abortion pills; eradicate censorship of abortion information available online; promote interventions to reduce stigma regarding abortion; and increase access to and the quality of abortion and post-abortion services 54 . Otherwise, women that have the right to access legal abortion services will be left unattended, searching for unsafe abortion as their only recourse. In this context, if service care for women in situations of abortion is not maintained and reinforced, maternal mortality is likely to increase significantly, in addition to the increase in deaths due to COVID-19, which makes the achievement of the Sustainable Development Goals even more difficult. 


\section{Contributors}

F. B. Pilecco and G. M. S. Menezes contributed in the study conception and design and analysis or interpretation of data, drafted the manuscript, approved its final version, and agreed to be accountable for all aspects of the article, ensuring that questions related to the accuracy or integrity of any part of the paper were investigated and resolved. C. A. McCallum contributed in the analysis or interpretation of data, reviewed the manuscript critically, approved its final version, and agreed to be accountable for all aspects of the article, ensuring that questions related to the accuracy or integrity of any part of the paper were appropriately investigated and resolved. M. C. C. Almeida, F. J. O. Alves, A. S. Rocha, N. Ortelan and L. Gabrielli contributed in the study conception and design, reviewed the manuscript critically, approved its final version, and agreed to be accountable for all aspects of the article, ensuring that questions related to the accuracy or integrity of any part of the paper were appropriately investigated and resolved.

\section{Additional informations}

ORCID: Flávia Bulegon Pilecco (0000-0001-83168797); Cecilia Anne McCallum (0000-0003-19277774); Maria da Conceição Chagas de Almeida (0000-0002-4760-4157); Flávia Jôse Oliveira Alves (0000-0003-1613-2270); Aline dos Santos Rocha (0000-0003-3806-6446); Naiá Ortelan (0000-00016535-748X); Lígia Gabrielli (0000-0002-51951979); Greice Maria de Souza Menezes (00000002-8393-2545).

\section{Acknowledgment}

We would like to thank the CoVida Network, which promoted the meeting among the researchers and contributed greatly to the elaboration of many of the discussions mentioned in this paper.

\section{References}

1. Morgan LM, Roberts EFS. Reproductive governance in Latin America. Anthropology \& Medicine 2012; 19:241-54.

2. Singer EO. Lawful sinners: reproductive governance and moral agency around abortion in Mexico. Cult Med Psychiatry 2018; 42:11-31.

3. Schnabel L. Religion and gender equality Worldwide: a country-level analysis. Social Indicators Research 2016; 129:893-907.

4. Fagan T, Dutta A, Rosen J, Olivetti A, Klein K. Family planning in the context of Latin America's universal health coverage agenda. Glob Health Sci Pract 2017; 5:382-98.

5. Bruno MM. Como vão os direitos reprodutivos na América Latina durante a pandemia do coronavírus. Gênero e Número 2020; 16 Apr. http://www.generonumero.media/como-es tao-os-direitos-reprodutivos-na-america-lati na-em-tempos-de-coronavirus/.

6. Bearak J, Popinchalk A, Ganatra B, Moller A-B, Tunçalp Ö, Beavin C, et al. Unintended pregnancy and abortion by income, region, and the legal status of abortion: estimates from a comprehensive model for 1990-2019. Lancet Glob Health 2020; 8:e1152-61.

7. Wenham C, Smith J, Davies SE, Feng H, Grépin KA, Harman S, et al. Women are most affected by pandemics - lessons from past outbreaks. Nature 2020; 583:194-8.

8. Bietsch K, Williamson J, Reeves M. Family planning during and after the West African Ebola crisis. Stud Fam Plann 2020; 51:71-86.

9. United Nations Population Fund Asia Pacific Regional Office. Coronavirus (2019-nCOV) guidance document. https://china.unfpa. org/sites/default/files/pub-pdf/APRO\%20 Coronavirus\%202019-nCoV\%20Guidance \%20Note-\%20final\%20\%2806\%20Feb\%20 2020\%29.pdf (accessed on 25/Jun/2020).

10. World Health Organization. COVID-19: operational guidance for maintaining essential health services during an outbreak. https:// www.who.int/publications-detail/covid19-operational-guidance-for-maintainingessential-health-services-during-an-outbreak (accessed on 25/Jun/2020).

11. Tolu LB, Feyissa GT. Guidelines and best practice recommendations on contraception and safe abortion care service provision amid COVID-19 pandemic: scoping review. Research Square 2020; 28 Apr. https://www. researchsquare.com/article/rs-25326/v1.

12. Tang K, Gaoshan J, Ahonsi B. Sexual and reproductive health (SRH): a key issue in the emergency response to the coronavirus disease (COVID- 19) outbreak. Reprod Health 2020; 17:59.

13. Ipas - Health. Access. Rights. Abortion remains essential during the coronavirus outbreak. https://www.ipas.org/our-work/coro navirus (accessed on 25/Jun/2020).

14. Bayefsky MJ, Bartz D, Watson KL. Abortion during the Covid-19 pandemic - ensuring access to an essential health service. N Engl J Med 2020; 382:e47. 
15. Li G, Tang D, Song B, Wang C, Shen Q, Xu C, et al. Impact of the COVID-19 pandemic on partner relationships, sexual and reproductive health: a cross-sectional online survey. J Med Internet Res 2020; 22:e20961.

16. Tanne JH. Coronavirus pandemic stirs fight over abortion rights in US. BMJ 2020; 369:m1733.

17. Center for Reproductive Rights. The World's abortion laws. https://reproductiverights. org/worldabortionlaws (accessed on 10/Aug/ 2020).

18. Madeiro AP, Diniz D. Serviços de aborto legal no Brasil - um estudo nacional. Ciênc Saúde Colet 2016; 21:563-72.

19. Skuster P, Khanal RC, Nyamato E. Relics of imperialism: US foreign policy on abortion in the COVID era. Sex Reprod Health Matters 2020; 28:1824319.

20. Riley T, Sully E, Ahmed Z, Biddlecom A. Estimates of the potential impact of the COVID-19 pandemic on sexual and reproductive health in low- and middle-income countries. Int Perspect Sex Reprod Health 2020; 46:73-6.

21. United Nations Population Fund. Coronavirus disease (COVID-19) pandemic: UNFPA Global Response Plan. https://www.unfpa.org/sites/ default/files/resource-pdf/COVID-19_-_ UNFPA_Global_Response_Plan_April_07.pdf (accessed on 26/Jun/2020).

22. Garrido L. Objeción de conciencia: un debate sobre la libertad y los derechos: seminario regional. Montevideo: Cotidiano Mujer; 2014.

23. Harper CC, Blanchard K, Grossman D, Henderson JT, Darney PD. Reducing maternal mortality due to elective abortion: potential impact of misoprostol in low-resource settings. Int J Gynaecol Obstet 2007; 98:66-9.

24. Zordo SD. The biomedicalisation of illegal abortion: the double life of misoprostol in Brazil. Hist Ciênc Saúde-Manguinhos 2016; 23:19-36.

25. Drovetta RI. Safe abortion information hotlines: an effective strategy for increasing women's access to safe abortions in Latin America. Reprod Health Matters 2015; 23:47-57.

26. Aiken ARA, Scott JG, Gomperts R, Trussell J, Worrell M, Aiken CE. Requests for abortion in Latin America related to concern about Zika virus exposure. N Engl J Med 2016; 375:396-8.

27. Diniz D, Castro R. O comércio de medicamentos de gênero na mídia impressa brasileira: misoprostol e mulheres. Cad Saúde Pública 2011; 27:94-102.

28. Diniz D, Medeiros M. Itinerários e métodos do aborto ilegal em cinco capitais brasileiras. Ciênc Saúde Colet 2012; 17:1671-81.

29. Donley G, Chen B, Borrero S. The legal and medical necessity of abortion care amid the COVID-19 pandemic. Social Science Research Network 2020; 28 Apr. https://papers.ssrn. com/abstract $=3584728$.

30. Jones RK, Lindberg L, Witwer E. COVID-19 abortion bans and their implications for public health. Perspect Sex Reprod Health 2020; 52:65-8.
31. Robinson EF, Moulder JK, Zerden ML, Miller AM, Zite NB. Preserving and advocating for essential care for women during the coronavirus disease 2019 pandemic. Am J Obstet Gynecol 2020; 223:219-220.e1.

32. Janiak E, Goldberg AB. Eliminating the phrase "elective abortion": why language matters. Contraception 2016; 93:89-92.

33. Gross MS, Harrington BJ, Sufrin CB, Faden RR. Rethinking "elective" procedures for women's reproduction during Covid-19. Hastings Cent Rep 2020; 50:40-3.

34. Costescu D, Guilbert E, Wagner M-S, Dunn S, Norman WV, Black A, et al. Induced abortion: updated guidance during pandemics and periods of social disruption. https://sogc. $\mathrm{org} /$ common/Uploaded\%20files/Induced\%20 Abortion\%20-\%20Pandemic\%20Guidance\%20 -\%20FINAL.PDF (accessed on 16/Jun/2020).

35. Bearak J, Jones RK, Nash E. Covid-19 abortion bans would greatly increase driving distances for those seeking care. Guttmacher Institute 2020; 4 Apr. https://www.guttmacher.org/ print/article/2020/04/covid-19-abortionbans-would-greatly-increase-driving-distanc es-those-seeking-care.

36. Senderowicz L, Higgins J. Reproductive autonomy is nonnegotiable, even in the time of COVID-19. Perspect Sex Reprod Health 2020; 52:81-5.

37. Ahmed A. How the COVID-19 response is altering the legal and regulatory landscape on abortion. J Law Biosci 2020; 7:1saa012.

38. McSpedon C. Reproductive care during COVID-19. Am J Nurs 2020; 120:19-20.

39. Bellizzi S, Ronzoni AR, Pichierri G, Cegolon L, Salaris P, Panu Napodano CM, et al. Safe abortion amid the COVID-19 pandemic: the case of Italy. Int J Gynaecol Obstet 2020; 150:254-5.

40. Cioffi A, Cioffi F, Rinaldi R. COVID-19 and abortion: the importance of guaranteeing a fundamental right. Sex Reprod Healthc 2020; 25:100538.

41. Vora KS, Saiyed S, Natesan S. Impact of COVID-19 on family planning services in India. Sex Reprod Health Matters 2020; 28:1785378

42. Caruana-Finkel L. Abortion in the time of COVID-19: perspectives from Malta. Sex Reprod Health Matters 2020; 28:1780679.

43. Ruggiero S, Brandi K, Mark A, Paul M, Reeves $\mathrm{MF}$, Schalit $\mathrm{O}$, et al. Access to later abortion in the United States during COVID-19: challenges and recommendations from providers, advocates, and researchers. Sex Reprod Health Matters 2020; 28:1774185.

44. Fulcher IR, Neill S, Bharadwa S, Goldberg AB, Janiak E. State and federal abortion Restrictions increase risk of COVID-19 exposure by mandating unnecessary clinic visits. Contraception 2020; 102:385-91.

45. Sackeim MG. Protecting access to abortion during the COVID-19 pandemic. Health Affairs 2020; 39:1456-8. 
46. De Zordo S, Mishtal J, Zanini G, Gerdts C. Consequences of gestational age limits for people needing abortion care during the COVID-19 pandemic. Sex Reprod Health Matters 2020; 28:1818377.

47. Foster DG, Biggs MA, Ralph L, Gerdts C, Roberts S, Glymour MM. Socioeconomic outcomes of women who receive and women who are denied wanted abortions in the United States. Am J Public Health 2018; 108:407-13.

48. Gerdts C, Dobkin L, Foster DG, Schwarz EB. Side effects, physical health consequences, and mortality associated with abortion and birth after an unwanted pregnancy. Womens Health Issues 2016; 26:55-9.

49. Brito CNO, Alves SV, Ludermir AB, Araújo TVB. Postpartum depression among women with unintended pregnancy. Rev Saúde Pública $2015 ; 49: 33$

50. Cohen MA, Powell AM, Coleman JS, Keller JM, Livingston A, Anderson JR. Special ambulatory gynecologic considerations in the era of COVID-19 and implications for future practice. Am J Obstet Gynecol 2020; 223:372-8.

51. Tanne JH. Covid-19: women's health campaigners sue FDA over access to medical abortion pills. BMJ 2020; 369:m2187.

52. Aiken ARA, Starling JE, Gomperts R, Tec M, Scott JG, Aiken CE. Demand for self-managed online telemedicine abortion in the United States during the coronavirus disease 2019 (COVID-19) pandemic. Obstet Gynecol 2020; 136:835-7.

53. Fay K, Kasier J, Turok D. The no-test abortion is a patient-centered abortion. Contraception 2020; 102:142.

54. Assis MP, Larrea S. Why self-managed abortion is so much more than a provisional solution for times of pandemic. Sex Reprod Health Matters 2020; 28:1779633.

55. Ott MA, Bernard C, Wilkinson TA, Edmonds BT. Clinician perspectives on ethics and COVID-19: minding the gap in sexual and reproductive health. Perspect Sex Reprod Health 2020; 52:145-9.

56. Gambir K, Kim C, Necastro KA, Ganatra B, Ngo TD. Self-administered versus provideradministered medical abortion Cochrane Database Syst Rev 2020; (3):CD013181.

57. Raymond EG, Grossman D, Mark A, Upadhyay UD, Dean G, Creinin MD, et al. Commentary: no-test medication abortion: a sample protocol for increasing access during a pandemic and beyond. Contraception 2020; 101:361-6.

58. Romanis EC, Parsons JA, Hodson N. COVID-19 and reproductive justice in Great Britain and the United States: ensuring access to abortion care during a global pandemic. J Law Biosci 2020; 7:1saa027.

59. Todd-Gher J, Shah PK. Abortion in the context of COVID-19: a human rights imperative. Sex Reprod Health Matters 2020; 28:1758394.

60. Church K, Gassner J, Elliott M. Reproductive health under COVID-19 - challenges of responding in a global crisis. Sex Reprod Health Matters 2020; 28:1-3.
61. Bateson DJ, Lohr PA, Norman WV, Moreau C, Gemzell-Danielsson K, Blumenthal PD, et al. The impact of COVID-19 on contraception and abortion care policy and practice: experiences from selected countries. BMJ Sex Reprod Health 2020; 46:241-3.

62. Haute Autorité de Santé. Interruption Volontaire de Grossesse (IVG) médicamenteuse à la 8ème et à la 9ème semaine d'aménorrhée (SA) hors milieu hospitalier. https://www.hassante.fr/jcms/p_3178808/fr/interruptionvolontaire-de-grossesse-ivg-medicamenteusea-la-8eme-et-a-la-9eme-semaine-d-amenor rhee-sa-hors-milieu-hospitalier (accessed on 16/Jun/2020).

63. Baird B, Millar E. Abortion at the edges: politics, practices, performances. Womens Stud Int Forum 2020; 80:102372.

64. Palomino S. La pandemia obstaculiza aún más el aborto seguro en América Latina. El País 2020; 9 Apr. https://elpais.com/socie dad/2020-04-09/la-pandemia-obstaculizaaun-mas-el-aborto-seguro-en-america-latina. html.

65. Oriéntame - Para decidir. Consulta virtual para aborto en casa. https://www.orientame.org. co/embarazo-no-deseado/consulta-virtual/ (accessed on 18/May/2020).

66. Boueri AG. Na pandemia, redes feministas se tornam ainda mais fundamentais para as mulheres que abortam na América Latina. Gênero e Número 2020; 17 Jun. http://www.genero numero.media/pandemia-redes-feministas -aborto-america-latina/.

67. Argentina aprova legalização do aborto: em que países da América Latina o procedimento já é legal. BBC News Brasil 2020; 30 Dec. https://www.bbc.com/portuguese/geral55476576.

68. Nugent C. These activists are helping women in Argentina get abortions during lockdown. Time 2020; 1 May. https://time.com/5830687/ argentina-abortion-coronavirus/.

69. Coordenação-Geral de Ciclos da Vida; Coordenação de Saúde das Mulheres, Departamento de Ações Programáticas Estratégicas, Secretaria de Atenção Primária à Saúde, Ministério da Saúde. Nota Técnica no 16/2020-COSMU/ CGCIVI/DAPES/SAPS/MS. Acesso à saúde sexual e saúde reprodutiva no contexto da pandemia da COVID- 19. Brasília: Ministério da Saúde; 2020.

70. Silva VR, Ferreira L. Só $55 \%$ dos hospitais que ofereciam serviço de aborto legal no Brasil seguem atendendo na pandemia. Gênero e Número 2020; 2 Jun. http://www.generonumero. media/so-55-dos-hospitais-que-ofereciamservico-de-aborto-legal-no-brasil-seguematendendo-na-pandemia/.

71. Corrêa $\mathrm{S}$. The case of the girl from Espírito Santo: is this a new turning point in the long journey for abortion rights in Brazil? https:// sxpolitics.org/the-case-of-the-girl-from-es pirito-santo-is-this-a-new-turning-point-inthe-long-journey-for-abortion-rights-in-bra zil/21576 (accessed on 12/Jan/2021). 
72. Ministério da Saúde. Portaria no 2.282, de 27 de agosto de 2020. Dispõe sobre o Procedimento de Justificação e Autorização da Interrupção da Gravidez nos casos previstos em lei, no âmbito do Sistema Único de Saúde-SUS. Diário Oficial da União 2020; 28 aug.

73. Ministério da Saúde. Portaria no 2.561, de 23 de setembro de 2020. Dispõe sobre o Procedimento de Justificação e Autorização da Interrupção da Gravidez nos casos previstos em lei, no âmbito do Sistema Único de Saúde-SUS. Diário Oficial da União 2020. 24 sep.

74. Consorcio Latinoamericano Contra el Aborto Inseguro. Mifepristona y misoprostol en seis países de América Latina: procesos de registro y disponibilidad. Lima: Consorcio Latinoamericano Contra el Aborto Inseguro; 2017.
75. Corrêa MCDV, Mastrella M. Aborto e misoprostol: usos médicos, práticas de saúde e controvérsia científica. Ciênc Saúde Colet 2012; 17:1777-84.

74. Lima JD. Misoprostol em falta no SUS causa prejuízos à saúde da mulher. https://www. abrasco.org.br/site/noticias/saude-da-popula cao/misoprostol-em-falta-no-sus-causa-pre juizos-a-saude-da-mulher/40211/ (accessed on 26/Jun/2020).

76. Kumar M, Daly M, De Plecker E, Jamet C, McRae M, Markham A, et al. Now is the time: a call for increased access to contraception and safe abortion care during the COVID-19 pandemic. BMJ Global Health 2020; 5:e003175. 


\section{Resumo}

A pandemia da COVID-19 pode agravar problemas existentes, dificultando o acesso ao aborto legal e resultando em um aumento dos abortos inseguros. O cenário pode ser ainda pior nos países de renda média e baixa, principalmente na América Latina, onde as leis sobre aborto já são restritivas e o acesso aos serviços é dificultado. Tivemos como objetivo, compreender como os diferentes países, com ênfase nos latino-americanos, têm lidado com os serviços de aborto legal no contexto da COVID-19. Para tal, foi realizada uma revisão narrativa sobre aborto e COVID-19. Os 75 artigos incluídos, além de outras referências relevantes, indicam que a pandemia impacta os serviços de saúde sexual e reprodutiva, ao agravar os problemas existentes e restringir o acesso aos direitos reprodutivos, incluindo o direito ao aborto legal. O impacto pode ser ainda mais sério nos países de renda baixa e média, principalmente na América Latina, onde o acesso ao aborto legal costuma ser restrito. A revisão das fontes no artigo destaca a necessidade urgente de manter em funcionamento os serviços de aborto legal, tanto da perspectiva das mulheres, em apoio aos seus direitos reprodutivos, quanto do compromisso internacional para atingir os Objetivos de Desenvolvimento do Milênio. Assim, os países da América Latina devem priorizar os direitos reprodutivos nas agendas nacionais e adaptar suas legislações para acomodar modelos alternativos de assistência ao aborto. Nossos resultados também destacam a necessidade de informações precisas sobre o funcionamento dos serviços de saúde sexual e reprodutiva, essenciais para compreender o impacto da pandemia sobre o aborto legal e para identificar os grupos mais afetados pelas mudanças.

Aborto; COVID-19; Aborto Legal; Direitos Sexuais e Reprodutivos

\section{Resumen}

La pandemia de COVID-19 puede acentuar problemas existentes, impidiendo el acceso al aborto legal, con el consiguiente incremento de abortos inseguros. Este escenario es quizás incluso peor en los países de bajos y medios ingresos, especialmente en Latinoamérica, donde las leyes del aborto son de por sí restrictivas y el acceso a los servicios ya se encuentra obstaculizado. Nuestro objetivo fue comprender cómo han lidiado diferentes países, poniendo énfasis en los latinoamericanos, con servicios legales de aborto en el contexto de la COVID-19. Por lo tanto, realizamos una revisión narrativa sobre el aborto y el COVID-19. Se incluyeron 75 artículos, así como otras referencias relevantes, indicando que la pandemia impacta en los servicios de salud sexual y reproductiva, lo que amplifica los problemas existentes y restringe el acceso a derechos reproductivos, tales como el aborto legal. Este impacto quizás fue incluso más fuerte en los paises con ingresos bajos y medios, especialmente en Latinoamérica, donde el acceso al aborto legal se encuentra restringido normalmente. La revisión de fuentes en este artículo subray a la necesidad urgente de mantener los servicios de aborto legal, tanto desde la perspectiva de las mujeres, apoyando sus derechos reproductivos, así como también desde el compromiso internacional, con el fin de alcanzar las Objetivos de Desarrollo del Milenio. De este modo, los países latinoamericanos deben situar los derechos reproductivos como prioridad en sus agendas y adaptar su legislación para incorporar modelos alternativos de atención al aborto. Nuestros resultados también destacam la necesidad de información precisa para el funcionamiento de los servicios de salud sexuales y reproductivos, como algo esencial para entender el impacto de la pandemia en el aborto legal, así como para identicar a los grupos más afectados por los cambios.

Aborto; COVID-19; Aborto Legal; Derechos Sexuales y Reproductivos
Submitted on $12 /$ Nov/2020

Final version resubmitted on 21/Jan/2021

Approved on 01/Feb/2021 